\title{
Czy wzrost częstości zachorowań na cukrzycę typu 1 ma związek $z$ nadmiarem higieny?
}

\author{
Can better hygiene generate an increase of type 1 diabetes frequency?
}

\section{STRESZCZENIE}

Liczne badania epidemiologiczne wskazują na stały wzrost częstości zachorowań na cukrzycę typu 1, zwłaszcza w krajach rozwiniętych, obserwowany równolegle ze zmniejszeniem zachorowań na choroby infekcyjne. Wyraźny gradient północ-południe dotyczący zachorowań na cukrzycę typu $1 \mathrm{i}$ inne schorzenia immunologiczne występuje w Stanach Zjednoczonych i Europie, dodatkowo w Europie obecny jest gradient zachód-wschód. W krajach rozwiniętych najmniejszą częstość zachorowań odnotowuje się na obszarach o najgorszych warunkach socjoekonomicznych i higienicznych. Istnieje kilka hipotez, które próbują tłumaczyć związek między większą częstością zachorowań na choroby alergiczne i autoimmunologiczne (w tym cukrzycę typu 1) a mniejszą ekspozycją na czynniki infekcyjne. Obejmują one między innymi koncepcję współzawodnictwa o antygen, zjawisko „bystander suppresion” czy hipotezę „polio”. Zgodnie z hipotezą higieny nadmierne przestrzeganie czystości może być przyczyną zaburzonej równowagi systemu immunologicznego, co z kolei może prowadzić do procesu autoimmunologicznego skierowanego przeciwko ko-

Adres do korespondencji:

lek. Agnieszka Niemiec

Klinika Diabetologii i Chorób Wewnętrznych PUM

ul. Siedlecka 2, 72-010 Szczecin-Police

Tel./faks: 48 (91) 4253858

e-mail: niemiec.agnes@gmail.com

Diabetologia Kliniczna 2015, tom 4, 1, 9-12

DOI: $10.5603 /$ DK.2015.0002

Copyright (c) 2015 Via Medica

Nadesłano: 18.12.2014

Przyjęto do druku: 12.01.2015 mórkom beta wysp trzustki i bezwzględnego niedoboru insuliny endogennej. (Diabet. Klin. 2015; 4, 1: 9-12)

Słowa kluczowe: cukrzyca typu 1, choroby autoimmunologiczne, hipoteza nadmiaru higieny

\section{ABSTRACT}

Variety of epidemiological studies indicate a steady increase in the incidence of type 1 diabetes mellitus, especially in industrialized countries, contrasted by a gradual decrease in the incidence of infectious diseases. There is an overall North-South gradient for type 1 diabetes and other immune disorders in North America and Europe, and West-East gradient in Europe. In developed countries lowest type 1 diabetes frequency is reported in the areas with the poorest socio-economic and hygiene conditions. There are several hypotheses that attempt to explain the relationship between lower exposure to transmissible agents, and a higher incidence of cases of allergic or autoimmune diseases (including type 1 diabetes mellitus). These are: the concept of the antigen competition, the phenomenon of bystander suppresion or "polio" hypothesis. According to hygiene hypothesis increased hygiene may contribute to imbalance of the autoimmune system, facilitating autoimmune reactions leading to destruction of islet beta cells and lack of endogenous insulin. (Diabet. Klin. 2015; 4, 1: 9-12)

Key words: type 1 diabetes mellitus, autoimmune disorders, hygiene hypothesis 
W ostatnich latach, z niejasnych przyczyn, częstość zachorowań na cukrzycę typu 1 istotnie wzrasta, zwłaszcza w krajach wysoko rozwiniętych, w tym w Stanach Zjednoczonych, krajach europejskich, a także w Polsce [1-3]. Niepokojący jest fakt, że częstość zachorowań gwałtownie rośnie u dzieci, zwłaszcza poniżej 5., a nawet 2. roku życia [4, 5]. Równocześnie, zarówno w Ameryce Północnej, jak i w Europie, utrzymuje się wyraźny gradient geograficzny północ-południe, z kilkakrotnie większą zapadalnością w obszarach północnych. W Europie największy wskaźnik zachorowań w grupie wiekowej 0-14 lat ma Finlandia - 41,4/100 tys., najmniejszy — kraje basenu Morza Śródziemnego, takie jak Grecja - 7,2 i południe Włoch - 6,2. Pośrednie wartości wskaźnika zachorowań mają Niemcy - 13,1, Czechy - 12,0, Belgia - 11,8/100 tys. [6]. Różnice związane z położeniem geograficznym próbowano tłumaczyć różnym stopniem nasłonecznienia i różną ilością witaminy D, która w warunkach eksperymentalnych może wywoływać efekt immunomodulujący, wpływając na ewentualne procesy destrukcji komórek beta [7]. Przeciwko takiej koncepcji przemawiają obserwacje dotyczące Sardynii, słonecznej wyspy leżącej na Morzu Śródziemnym, gdzie wskaźnik zachorowań na cukrzycę jest większy niż w Finlandii i wynosi 49,3/100 tys. W opublikowanym niedawno badaniu duńskim, którym objęto bardzo dużą grupę dzieci i młodzieży ze świeżo rozpoznaną cukrzycą typu 1, nie wykazano żadnych nieprawidłowości w stężeniach 25-hydroksywitaminy D oznaczanych w chwili zachorowania [8].

Dość gwałtowny wzrost zachorowań na cukrzycę typu 1, obserwowany w różnych krajach trudno wytłumaczyć udziałem czynników genetycznych, od dawna uwzględnianych w patogenezie choroby, ponieważ w wielu przypadkach populacje danych krajów są stabilne pod względem genetycznym. Do takich krajów należy Polska, w której wskaźnik zachorowań na cukrzycę typu 1 u dzieci poniżej 15. roku życia wzrósł w latach 1989-2004 z 5,4 do 17,7/100 tys./rok. Obserwacje te zdecydowanie wskazują na udział czynników zewnętrznych, środowiskowych. Wskazują na to także wyniki badań przeprowadzonych w Karelii, obejmującej stosunkowo nieduży obszar położony na pograniczu Finlandii i Rosji $[9,10]$. Roczna częstość zachorowań na cukrzycę typu 1 u dzieci poniżej 15. roku życia wynosi po stronie rosyjskiej 7,4/100 tys./rok, natomiast po stronie fińskiej wskaźnik ten jest prawie 6 razy większy i wynosi 41,4. Badania alleli genotypu HLA DQ, które uważa się za predysponujące do rozwoju cukrzycy, nie wykazały różnic w obydwu ocenianych populacjach. Skryty, długotrwały proces autoimmunologiczny, który miałby doprowadzić do zniszczenia komórek wysp trzustki także wydaje się mało prawdopodobny. Mimo dużej różnicy w częstości zachorowań na cukrzycę u dzieci z Karelii fińskiej i rosyjskiej częstość występowania przeciwciał skierowanych przeciwko antygenom wysp trzustki lub insulinie [przeciwciał przeciwwyspowych (ICA, islet-cell antibodies), przeciwciał przeciwko dekarboksylazie kwasu glutaminowego (GAD, glutamate decarboxylase antibodies) przeciwciał przeciw insulinie endogennej (IAA, anti-insulin antibodies)], które oznaczano u wielu tysięcy zdrowych dzieci w wieku szkolnym, była podobna na obydwu terytoriach. Częstość występowania przeciwciał w różnych grupach etnicznych zamieszkujących Karelię rosyjską (Finowie, Rosjanie i inni) także była identyczna. Na istotny udział czynników środowiskowych wskazują dane dotyczące bardzo istotnego wzrostu częstości zachorowań na cukrzycę typu 1 u osób z populacji o niskim wskaźniku zachorowalności, jeśli migrują one do krajów o większej częstości zachorowań. U dzieci pochodzenia azjatyckiego wskaźnik ten jest niski i wynosi 3,1/100 tys./rok. Po zmianie miejsca zamieszkania rodziców, którzy wyemigrowali do Wielkiej Brytanii, wskaźnik zachorowań u dzieci z tej populacji wzrósł do 11,7/100 tys./rok i był zbliżony do wskaźnika zachorowań innych dzieci mieszkających w tym kraju [11]. Wzrost częstości zachorowań na cukrzycę typu 1 obserwuje się już w pierwszym pokoleniu imigrantów.

Zachorowania na cukrzycę typu 1 wykazują pewną sezonowość. W naszej strefie klimatycznej liczba zachorowań istotnie wzrasta w miesiącach jesienno-zimowych [3]. Wskazuje to na potencjalny związek z infekcjami wirusowymi, które w tym czasie występują powszechnie. Możliwość bezpośredniego udziału wirusów w destrukcji komórek wysp trzustki brana jest pod uwagę od dawna. W 1979 roku preparaty mikroskopowe trzustki 10-letniego chłopca ze świeżo rozpoznaną cukrzycą typu 1, który zmarł z powodu ciężkiej kwasicy ketonowej, wykazały nacieki limfocytarne wysp Langerhansa i martwicę komórek beta [12]. W surowicy chłopca w ciągu 7 dni hospitalizacji zaobserwowano istotny wzrost miana przeciwciał przeciwko wirusowi Coxsackie B4, należącego do rodziny enterowirusów. Homogenaty trzustki pobranej po śmierci chłopca, przeniesione na hodowle komórkowe, pozwoliły na wyizolowanie wirusa Coxsackie B4. Po wszczepieniu wyizolowanego materiału myszom obserwowano u nich hiperglikemię, nacieki zapalne wysp trzustkowych i martwicę komórek beta, w których wykazano obecność antygenów wirusa [12]. Związek z zakażeniami enterowirusami wydaje się możliwy, bowiem niektóre z nich wykazują tropizm do komórek wysp trzustkowych. W modelach eksperymentalnych zaobserwowano, że mogą one uszkadzać komórki beta [13]. Kazuistyczne doniesienia sprzed lat 
zostały potwierdzone w licznych badaniach. Przegląd systematyczny i metaanaliza wyników 24 badań dotyczących powiązań między infekcjami enterowirusowymi a cukrzycą typu 1 wskazują jednoznacznie na bardzo silny związek między tego typu zakażeniami a zachorowaniem na cukrzycę typu 1 [14]. Wykazano także, że u chorych z cukrzycą typu 1 enterowirusy mogą być obecne w przewodzie pokarmowym przez dłuższy czas od zachorowania. W bioptatach śluzówki jelita cienkiego tych osób wykazano znacznie większą ilość RNA enterowirusów i większe nacieki zapalne niż w analogicznych próbkach osób zdrowych czy osób z celiakią [15]. Zmiany miały charakter przetrwały i utrzymywały się nawet po 12 miesiącach od zachorowania.

Jeśli przyjąć, że zachorowania na cukrzycę typu 1 istotnie mają związek z przebytą infekcją wirusową (jawną lub utajoną), zaskakujące stają się informacje, że częstość zachorowań na cukrzycę typu 1 w różnych krajach jest dokładnie odwrotna niż częstość zachorowań na gruźlicę - jest najmniejsza tam, gdzie chorobowość z powodu gruźlicy jest największa. Zazwyczaj sytuacja taka dotyczy krajów o niższym poziomie życia, w których panują gorsze warunki higieniczne [16]. Wydaje się, że obserwacja ta nie jest wynikiem braku odpowiednich danych epidemiologicznych dotyczących cukrzycy typu 1, bowiem zachorowania dotyczą głównie dzieci, młodzieży i młodych dorosłych, objawy choroby są dość gwałtowne, a jej zdiagnozowanie proste. $Z$ tego względu z dużym prawdopodobieństwem można przyjąć, że większość przypadków jest rejestrowana. W krajach rozwiniętych, z dobrze zorganizowaną opieką medyczną i dobrze prowadzonymi rejestrami chorych, cukrzyca typu 1 rzadziej występuje w tych grupach społecznych, które mają niższy status socjoekonomiczny, większą liczbę mieszkańców na metr kwadratowy i gorsze warunki higieniczne $[17,18]$.

Badania eksperymentalne wydają się potwierdzać możliwość wpływu nadmiaru higieny na większą częstość zachorowań na cukrzycę typu 1. U myszy laboratoryjnego szczepu NOD [NOD mice (non-obese diabetic mouse) - nieotyłe myszy z cukrzycą] cukrzyca rozwija się w 2.-3. miesiącu życia. Częstość zachorowań oraz objawy niedoboru insuliny zależą w dużej mierze od warunków chowu zwierząt. Są one nasilone u zwierząt urodzonych przez cięcie cesarskie, a następnie hodowanych w sterylnych izolatorach [19] Częstość zachorowań na cukrzycę wśród myszy NOD maleje, gdy są one hodowane w gorszych warunkach higienicznych. Równocześnie wykazano, że u zwierząt można całkowicie zapobiec wystąpieniu cukrzycy, jeśli zarazi się je pewnymi szczepami bakterii, wirusów lub pasożytów jelitowych [20-22]. Efekt protekcyjny w zakresie zachorowań na cukrzycę typu 1 jest przy tym zdecydowanie wyraźniejszy w przypadku infekcji przewlekłych. Istnieją doniesienia, że przewlekłe zakażenie pasożytami jelitowymi, w tym owsikami, może istotnie łagodzić przebieg chorób atopowych u ludzi i zapobiegać cukrzycy u myszy NOD [23]. Obecność owsików może w istotny, modulujący sposób wpływać na układ odpornościowy, w tym limfocyty $\mathrm{T}$ regulatorowe, zapobiegając innym schorzeniom o podłożu immunologicznym. Równocześnie wiadomo, że do niedawna - w połowie XX wieku — około 50\% dzieci w Europie i Północnej Ameryce było zainfekowanych owsikami, przy czym infekcje przebiegały zwykle łagodnie i bezobjawowo.

Obserwacje te stały się przesłanką do zbudowania hipotezy, że ekspozycja na czynniki infekcyjne, do której dochodzi we wczesnym dzieciństwie z powodu gorszych warunków higienicznych, może stanowić czynnik protekcyjny, zmniejszający ryzyko zachorowania na cukrzycę typu 1 [24]. Równocześnie, zgodnie z tą koncepcją, nadmiar higieny i mniejsza możliwość kontaktu z czynnikami infekcyjnymi może sprzyjać zachorowaniom na cukrzycę typu 1. Bardzo podobny pogląd dotyczy zwiększonej częstości zachorowań na schorzenia autoimmunologiczne i alergiczne, takie jak stwardnienie rozsiane, choroba Crohna, atopowe zapalenie skóry czy astma [25].

Istnieje kilka hipotez, które próbują tłumaczyć związek między mniejszą ekspozycją na czynniki infekcyjne a większą częstością zachorowań na choroby autoimmunologiczne (w tym cukrzycę typu 1) lub alergiczne. Pod uwagę brana jest między innymi koncepcja współzawodnictwa o antygen, wskazująca na zmienione funkcjonowanie układu immunologicznego. Antygeny związane z czynnikami infekcyjnymi są zwykle silnymi antygenami, które uruchamiają i w istotny sposób angażują układ immunologiczny. Ograniczenie kontaktu $z$ antygenami infekcyjnymi może prowadzić do większej gotowości systemu immunologicznego do rozpoznawania i reagowania na słabe antygeny, jakimi są antygeny własne lub antygeny otoczenia, co może uruchomić proces autoimmunologiczny lub proces alergiczny. Druga z koncepcji ma związek ze zjawiskiem "bystander suppresion", polegającym na tym, iż w czasie odpowiedzi immunologicznej na silny antygenowo czynnik infekcyjny dochodzi do supresji odpowiedzi na czynnik o słabszej sile działania. Zgodnie z teorią nadmiaru higieny brak kontaktu z wieloma bakteriami, wirusami czy pasożytami może skutkować brakiem tłumienia odpowiedzi immunologicznej na inne, słabe antygeny, w tym antygeny własne [21, 22]. Jeszcze inna hipoteza, zwana hipotezą „polio”, wskazuje na możliwość rozwoju cukrzycy typu 1 na skutek wybiórczej destrukcji komórek wysp trzustki 
przez niektóre szczepy wirusów należące do rodziny enterowirusów, podobnie jak ma to miejsce w przypadku poliomielitis wywołanej przez wirusy Polio, również należące do rodziny enterowirusów (choroba Heinego-Medina, zapalenie rogów przednich rdzenia) $[26,27]$. Infekcja wirusami Polio powoduje wybiórcze uszkodzenie motoneuronów rogów przednich rdzenia kręgowego, co prowadzi do niedowładów lub porażenia mięśni szkieletowych. Epidemię zachorowań na poliomielitis w latach 50. XX wieku (również w Polsce) przypisuje się poprawie warunków higienicznych po okresie drugiej wojny światowej. Równocześnie ocenia się, że na chorobę zapadało mniej niż 1\% ludzi, którzy mieli kontakt $z$ wirusem. Wprowadzenie szczepionki zawierającej żywą, lecz atenuowaną postać wirusa, pozwoliło na uzyskanie odporności na szczepy chorobotwórcze. Analogia między zachorowaniem na cukrzycę typu 1 a zachorowaniem na polio dotyczy infekcji wirusami należącymi do tej samej, dużej rodziny enterowirusów, możliwości ich bardzo wybiórczego działania destrukcyjnego na tkanki oraz osobniczej, niewielkiej podatności na chorobę. W przypadku cukrzycy typu 1 nadmiar higieny ma uniemożliwiać kontakt z łagodnymi formami wirusów Coxsackie, które najczęściej powodują pospolite, sezonowe infekcje górnych dróg oddechowych. Kontakt z tymi wirusami daje być może odporność na infekcje szczepami bardziej agresywnymi, które mogą prowadzić do destrukcji wysp trzustki. Infekcja wywołana tymi szczepami wirusów w przypadku osób, które wcześniej nie miały kontaktu z formami łagodniejszymi, mogłaby skutkować zachorowaniem na cukrzycę typu 1.

Opisane powyżej hipotezy są oparte na obserwacjach, analogiach i przypuszczeniach. Żadna z nich, jak dotąd, nie została udowodniona i potwierdzona.

\section{Oświadczenie o konflikcie interesów}

Autorzy nie zgłaszają konfliktu interesów.

\section{PIŚMIENNICTWO}

1. Dabelea D., Mayer-Davis E.J., Saydah S. i wsp. Prevalence of type 1 and type 2 diabetes among children and adolescents from 2001 to 2009. JAMA 2014; 311: 1778-1786.

2. Patterson C.C., Gyurus E., Rosenbauer J. i wsp. Trends in childhood type 1 diabetes incidence in Europe during 1989-2008: evidence of non-uniformity over time in rates of increase. Diabetologia 2012; 55: 2142-2147.

3. Jarosz-Chobot P., Polanska J., Szadkowska A. i wsp. Rapid increase in the incidence of type 1 diabetes in Polish children from 1989 to 2004, and predictions from 2010 to 2025. Diabetologia 2011; 54: 508-515.

4. Patterson C.C., Dahlquist G.G., Gyurus E., Green A., Soltesz G. Incidence trends for childchood type 1 diabetes in Europe during 1989-2003 and predicted new cases 2005-20. A multicentre prospective registration study. Lancet 2009; 373: 2027-2033.

5. Chobot A., Polańska J., Deja G., Jarosz-Chobot P. Incidence of type 1 diabetes among Polish children ages 0-14 years from
1989-2012. Acta Diabetol. 2014; 8: e1-e2, DOI 10.1007/s00592014-0682-z.

6. Rewers M., Krętowski A. Epidemiologia cukrzycy typu 1. W: Sieradzki J. (red.). Cukrzyca. T. 1. Via Medica, Gdańsk 2006: 151-169.

7. Mora J.R., Iwata M., van Andrian U.H. Vitamin effects on the immune system: vitamins $A$ and $D$ take centre stage. Nat. Rev. Immunol. 2008; 8: 685-698.

8. Thorsen S.U., Mortensen H.B., Carstensen B. i wsp. No difference in vitamin d levels between children newly diagnosed with type 1 diabetes and their healthy siblings: a 13-year nationwide Danish study. Diabetes Care 2013, 36, e157-e158. DOI 10.2337/dc13-0342.

9. Kondrashova A., Reunanen A., Romanov A. i wsp. A six-fold gradient in the incidence of type 1 diabetes AT the ekstern border of Finland. Ann. Med. 2005; 37: 67-72.

10. Kondrashova A., Viskari H., Kulmala P. i wsp. Signs of beta-cell autoimmunity in nondiabetic schoolchildren: a comparison between Russian Karelia with a low incidence of type 1 diabetes and Finland with a high rate. Diabetes Care 2007; 30: 95-100.

11. Bodansky H.J., Staines A., Stephenson C., Haigh D., Cartwright R. Evidence for an environmental effect in the aetiology of insulin dependent diabetes in a transmigratory population. BMJ 1992; 304: 1020-1022.

12. Yoon J.W., Austin M., Onodera T., Notkins A.L. Isolation of a virus from the pancreas of a child with diabetic ketoacidosis. N. Engl. J. Med. 1979; 300: 1173-1179.

13. Ylipaasto P., Klingel K., Lindberg A.M. i wsp. Enterovirus infection in human pancreatic islet cell, islet tropism in vivo and receptor involvement in cultures islet beta cells. Diabetologia 2004; 47: 225-239.

14. Yeung W.C., Rawlinson W.D., Craig M.E. Enterovirus infection and type 1 diabetes mellitus: systematic review and meta-analysis of observational molecular studies. BMJ 2011; 342: d35. Doi: 10.1136/bmj.d35.

15. Oikarinen M., Tauriainen S., Oikarinen S. i wsp. Type 1 diabetes is associated with enterovirus infection in gut mucosa. Diabetes 2012; 61: 687-691.

16. Airaghi L., Tedeschi A. Negative association between occurrence of type 1 diabetes and tuberculosis incidence at population level. Acta Diabetol. 2006; 43: 43-45.

17. Patterson C.C., Carson D.J., Hadden D.R. Epidemiology of childhood IDDM in Northern Ireland 1989-1994: low incidence in areas with highest population density and most household crowding. Northern Ireland Diabetes Study Group. Diabetologia 1996; 39: 1063-1069.

18. Cardwell C.R., Carson D.J., Patterson C.C. Higher incidence of childhood-onset type 1 diabetes mellitus in remote areas: a UK regional small-area analysis. Diabetologia 2006; 49: 2074-2077.

19. Bach J.F. The effect of infections on susceptibility to autoimmune and allergic diseases. N. Engl. J. Med. 2002; 347: 911-920.

20. Sadelain M.W., Qin H.Y., Lauzon J., Singh B. Prevention of type I diabetes in NOD mice by adjuvant immunotherapy. Diabetes 1990; 39: 583-589.

21. Wilberz S., Partke H.J., Dagnaes-hansen F., Herberg L. Persistent MHV (mouse hepatitis virus) infection reduces the incidence of diabetes mellitus in non-obese diabetic mice. Diabetologia 1991; 34: 2-5.

22. Zaccone P., Burton O., Miller N., Jones F.M., Dunne D.W., Cooke A. Schistosoma mansoni egg antigens induce Treg that participate in diabetes prevention in NOD mice. Eur. J. Immunol. 2009; 39: 1098-1107.

23. Gale E.A. A missing link in the hygiene hypothesis? Diabetologia 2002; 45: 588-594.

24. Bach J.F., Chatenoud L. The hygiene hypothesis: an explanation for the increased frequency of insulin-dependent diabetes. Cold Spring Harb. Perspect. Med. 2012; 4: a007799.

25. Okada H., Kuhn C., Feillet H, Bach J.F. The "hygiene hypopthesis" for autoimmune and allergic diseases. Clin. Exp. Immunnol. 2010; 160: 1-9.

26. Hyöty H. Enterovirus infections and type 1 diabetes. Ann. Med. 2002; 34: 138-147.

27. Tracy S., Drescher K.M., Chapman N.M. Enteroviruses and type 1 diabetes. Diabetes Metab. Res. Rev. 2011; 27: 820-823. 